\title{
Impact of some Macroeconomic Variables on Tax Revenue in Nigeria
}

\author{
S. Atolagbe and *A. A. Abiodun \\ Department of Statistics, University of llorin \\ [ ${ }^{*}$ Corresponding Author: E-mail: alfredabiodun1@gmail.com]
}

\section{ABSTRACT}

The knowledge of the relationship between tax revenue and the interplay of macroeconomic factors is necessary to maximize the gains of the proposed elimination of non-tariff barriers by the African Union. This study was carried out to investigate the impact of trade liberalization and six macroeconomic variables on tax revenue in Nigeria from 1981-2019, using the autoregressive distributed lag (ARDL) approach to cointegration and the Error Correction Model (ECM). The unrestricted error-correction model was specified in the study by modifying ARDL model. Total tax and domestic tax revenues were predicted by trade liberalization and most macroeconomic variables examined. A unit increase in trade liberalization triggered an increase of $3 \%$ in both total and domestic tax revenues when all other variables in the model were held constant. The results of ECM showed that short run and long run equilibrium were present in the system. The macroeconomic variables found to be predictors of both domestic and external tax revenues are share of petroleum and mining in GDP, foreign direct investment, share of agriculture in GDP, per capita income, exchange rate and inflation rate. These are therefore important to explain tax revenue in Nigeria. The key policy recommendation for improved and sustained tax revenue is to embark on comprehensive trade liberalization policies as well as regulate changes in macroeconomic variables.

Keywords: Trade liberalization, Total tax revenue, Domestic Tax revenue, Error correction model

\section{INTRODUCTION}

Taxation is an age long event (Amahalu and Ezechukwu, 2017). Tax is a compulsory charge imposed by a public authority on the income and properties of individuals and companies as stipulated by the government Decree, Acts or Laws irrespective of the exact amount of service of the payer in return (Omotosho, 2001; Okeke et al., 2018). Tax is defined by the Institute of Chartered accountants of Nigeria (2006) and Chartered Institute of Taxation of Nigeria (2002) as an enforced contribution of money to government pursuant to a defined authorized legislation. Tax could be levied directly on personal or corporate income (called a direct tax) or levied on the price of a good or service (indirect tax) (Worlu and Nkoro, 2012). Tax is one of the most important sources of public revenue which a government uses to provide social and welfare services and also to achieve national macroeconomic objectives especially in the areas of fiscal and monetary policies. Every corporate organization is therefore expected to pay taxes as one of its responsibilities to the society. Taxation aims to finance government expenditure and to redistribute wealth which translates to financing development of the country (Ola, 2001; Jhingan, 2004, Musgrave and Musgrave, 2004; Bhartia, 2009; Ordu and Anele, 2015).

The use of tax as an instrument of social engineering is to stimulate general and/or sectoral economic growth (Sanni, 2007). Generally, the maximization of tax revenue is incompatible with the maximization of Gross Domestic Product (GDP) (Ma, 2001). While it was argued by Ergete and Bev (2012), James and Robert (2006), Ma (2001) and Peden (1991) that higher taxes reduce economic growth, Feng and Suyono (2014) in their findings reported that tax could have both positive and negative effects on the economy. The sustainability of revenues from tax has been greatly affected by tax evasion, which is an illegal non-payment or underpayment of tax. The regional economic outlook of the International Monetary Fund (IMF) (2018) reported that Nigeria, the Africa's most-populous 


\section{Atolagbe and Abiodun: Impact of some Macroeconomic Variables on Tax Revenue in Nigeria}

nation and largest economy, with a population of about 200 million people, has the lowest tax-toGDP ratio among Sub-Saharan countries, with tax to GDP ratio of 5.9 percent compared to 24.7 percent for South Africa (Herbert et al., 2018). Effectively combating the scourge of tax evasion requires deeper understanding of the factors influencing the taxpayer's decision in tax matters, and then to quantify it in order to know its magnitude and its range in public finances (Angour and Nmili, 2019). Apart from being an essential fiscal policy tool and one of the primary sources of public revenue across the world, studies reveal the interaction effects of taxation play a pivotal role in the economy (Nwaorgu et al., 2016).

The relationship between tax revenue and the interplay of macroeconomic factors has received considerable research attentions over the years especially because correct knowledge of factors affecting tax revenue does not only facilitate proper economic and fiscal planning but also promotes economic growth and development. The global economic cooperation has led to trade openness or reduction and removal of barriers to free trade and the World Trade Organization (2013) has reported this as one of the major factors that have influenced the growth in world trade. One of the major factors that influence tax revenue istrade liberalization and this has frequently been at the center of an economic development strategy in Sub-Saharan Africa. Trade liberalization has been known to be associated with the reduction, removal and elimination of taxes on goods and services (including tariffs and import duties) as well as relaxing thequantitative barriers which may be accompanied or supported by currency devaluation and domestic tax reform (Mehdi et al., 2014).

The Nigerian government in recent decades has engaged in the search for the appropriate policy strategy to stimulate tax revenue and boost the revenue profile of the government (Saibu and Sinbo, 2013). In analyzing macroeconomic determinants of tax revenue in Nigeria using time series data from 1970 - 2011, Saibu and Sinbo (2013) deployed the autoregressive distributed lag (ARDL) method to establish both the long run and short run relationship among the variables, namely, tax revenue, trade openness, official exchange rate, inflation, real GDP and the ratio of external debt to GDP. Results showed that trade liberalization policy had positive effect on tax revenue contrary to expectation. Also, the growth rate of economic activity impacted positively on tax revenue in Nigeria while exchange rate depreciation and inflation rate were found to have negative effect on tax revenue.

Kwanashie et al. (1998) examined the impact of exchange rate and trade liberalization policies on Nigerian non-oil exports for the period 1986-1992. The findings showed that prices (relative and absolute) of export products rose sharply but the expansion was not sustainable. Besides, foreign prices of the commodities contracted over the period, suggesting that the rise in domestic prices might be due to the monotonic and rapid depreciation of the exchange rate of the naira. In a related study in Pakistan, Sumera et al. (2012) deployed econometric methods to estimate the impact of various factors on trade taxes and tax revenues. Results showed that exchange rate and population were negatively related to tax revenue, while trade openness, trade share and GDP showed a positive relationship with tax revenue. Tanzi (1992) in his study found that the share of agriculture in GDP may have an inverse influence on the tax share from both the demand and supply point of view. That is, as the share of agriculture in GDP increased, the amount of money collected as tax revenue decreased. This finding is supported by Gupta, (2007) who found that tax revenue is negatively correlated with share of agriculture in GDP. However, the relationship between share of agriculture in GDP and tax revenue may be positive in countries with large share of agricultural products in total exports (Agbeyegbe et al., 2006). Inflation indicates the quality and stability of a country's macroeconomic policies and can affect a 
country's tax revenue. Generally, it has a negative effect on a country's tax performance as it reduces the purchasing power of people and tax collection (McMahon and Schmidt-Hebbel, 2000). Exchange rate and share of foreign direct investment in GDP are also exogenous determinants of tax revenue. However, their relationship with tax revenue alongside trade liberalization has not been adequately explored in Nigeria. The current study therefore aims to fill this gap by investigating the relationship between tax revenue and some microeconomic variables with emphasis on trade liberalization proxied by trade openness in Nigeria using time series analysis

\section{MATERIAL AND METHODS \\ Data}

Annual time series data on Nigeria's tax revenue, trade openness and six macroeconomic variables from 1981 - 2019 were obtained from secondary sources shown in the Appendix. There were three dependent variables in this study, namely, total tax revenue, domestic tax revenue and external tax revenue. Trade liberalization was the independent variable of interest while the six macroeconomic variables, viz exchange rate, inflation rate, per capita income, foreign direct investment, share of agriculture in GDP and share of petroleum and mining in GDP were used as control variables in this study. Measurement indicators of all the variables are presented in the Appendix.

\section{Model Specification}

$$
\begin{aligned}
& \boldsymbol{T T G D P}_{\boldsymbol{t}}=\alpha_{0}+\sum_{i=1}^{p} \beta_{i} \operatorname{TTGDP}_{t-i}+\sum_{i=0}^{q 1} \Phi_{i} \operatorname{TROPENS}_{t-i}+\sum_{i=0}^{q 2} \gamma_{i} I N F R_{t-i}+\sum_{i=0}^{q 3} \emptyset_{i} E X R_{t-i}+\sum_{i=0}^{q 4} \varphi_{i} \operatorname{AGSGDP}_{t-i} \\
& +\sum_{i=0} \varphi_{i} \operatorname{AGSGDP}_{t-i}+\sum_{i=0} \delta_{i} \text { PCI }_{t-i}+\sum_{i=0} \lambda_{i} \text { FDISGDP }_{t-i}+\sum_{i=0} \psi_{i} \text { PNMSGDP } P_{t-i} \\
& +\varepsilon_{t} \\
& \boldsymbol{D T G D P}_{\boldsymbol{t}}=\alpha_{0}+\sum_{i=1}^{p} \beta_{i} D T G D P_{t-i}+\sum_{i=0}^{q 1} \Phi_{i} \operatorname{TROPENS}_{t-i}+\sum_{i=0}^{q 2} \gamma_{i} I N F R_{t-i}+\sum_{i=0}^{q 3} \emptyset_{i} E X R_{t-i}+\sum_{i=0}^{q 4} \varphi_{i} \operatorname{AGSGDP}_{t-i}
\end{aligned}
$$

Three models are considered in this study:

Model I: Examining the relationship between total tax revenue and trade liberalization alongside other macroeconomic variables.

Model II: Examining the relationship between domestic tax revenue and trade liberalization alongside other macroeconomic variables.

Model III: Examining the relationship between external tax revenue and trade liberalization alongside other macroeconomic variables.

An ARDL regression model (Pesaran et al, 2001) in its generalized form was specified as follows:

$$
\begin{aligned}
& Y_{t}=\mu+\sigma t+\emptyset_{1} Y_{t-1}+\ldots+\emptyset_{p} Y_{t-p}+ \\
& \beta_{0} X_{t}+\beta_{1} X_{t-1}+\cdots+\beta_{q} X_{t-q}+\varepsilon_{t},
\end{aligned}
$$

Where $\mu, \mathrm{t}$, and $\varepsilon_{t}$ are intercept, time trend and white noise error term respectively, $X_{t}$ and $Y_{t}$ are stationary variables. The above model is called an autoregressive-distributed lag model of order $p$ in the autoregressive component and of order $q$ in the distributed lag; this is often written as ARDL $(p, q)$, or alternatively $\operatorname{ADL}(p, q)$.

To examine the relationship between the dependent variables (total tax revenue, domestic tax revenue and external tax revenue) and the independent variable (trade liberalization) including the six control variables (exchange rate, inflation rate, per capita income, foreign direct investment, share of agriculture in GDP and share of petroleum and mining in GDP), the following three autoregressive distributed lag models were specified as 


\section{Atolagbe and Abiodun: Impact of some Macroeconomic Variables on Tax Revenue in Nigeria}

$$
\begin{aligned}
& +\sum_{i=0}^{q 4} \varphi_{i} \operatorname{AGSGDP}_{t-i}+\sum_{i=0}^{q 5} \delta_{i} \text { PCI }_{t-i}+\sum_{i=0}^{q 6} \lambda_{i} F D I S G D P_{t-i}+\sum_{i=0}^{q 7} \psi_{i} \text { PNMSGDP }_{t-i} \\
& +\varepsilon_{t} \\
& \boldsymbol{E X T G D P}_{\boldsymbol{t}}=\alpha_{0}+\sum_{i=1}^{p} \beta_{i} \operatorname{EXTGDP}_{t-i}+\sum_{i=0}^{q 1} \Phi_{i} \operatorname{TROPENS}_{t-i}+\sum_{i=0}^{q 2} \gamma_{i} \operatorname{INFR}_{t-i}+\sum_{i=0}^{q 3} \emptyset_{i} \operatorname{EXR}_{t-i}+\sum_{i=0}^{q 4} \varphi_{i} \operatorname{AGSGDP}_{t-i} \\
& +\sum_{i=0}^{q 4} \varphi_{i} A_{G S G D P} P_{t-i}+\sum_{i=0}^{q 5} \delta_{i} \text { PCI }_{t-i}+\sum_{i=0}^{q 6} \lambda_{i} \text { FDISGDP }_{t-i}+\sum_{i=0}^{q 7} \psi_{i} \text { PNMSGDP }_{t-i}+ \\
& \varepsilon_{t}
\end{aligned}
$$

where:

$T_{T G D P}=$ Total Tax Revenue at time $t$, measured as ratio of total tax revenue to GDP (current prices) in percentage.

$\operatorname{DTGDP}_{\mathrm{t}}=$ Domestic Tax Revenue at time $\mathrm{t}$, measured as ratio of sum of Domestic (Direct \& Indirect) Tax Revenue to GDP (current prices) in percentage.

EXTDGP $_{\mathrm{t}}=$ External Tax Revenue at time $\mathrm{t}$, measured as ratio of customs and excise duties to GDP (current prices) in percentage.

TROPENS $_{t}=$ Trade openness at time $t$, measured as ratio of sum of export and import to GDP, which is a constant.

$I N F R_{t}=$ Inflation rateat time $t$, measured in percentage.

$E X R_{t}=$ Exchange rate at time $t$, measured in percentage.

AGSGDP $_{t}=$ Share of agriculture in GDPat time $t$, measured as ratio of Agriculture to GDP (constant) in percentage.

$\mathrm{PCl}_{\mathrm{t}}=$ Level of economic development at time $\mathrm{t}$, measured by Real GDP per Capita.

FDISDGP $=$ Foreign Direct Investment at time $t$, measured as ratio of Net inflow of FDI to GDP in percentage.
PNMSGDP ${ }_{t}=$ Share of mining and petroleum in GDPat time t, measured as Ratio of Mining and Petroleum to GDP (constant) in percentage.

$\alpha_{0}=$ Intercept.

$\varepsilon_{t}=$ Error term.

In order to determine the degree of stationarity, a unit root testing was carried out through the Augmented Dickey-Fuller (1981) (ADF) test which is applied to the model given as

$$
\begin{aligned}
& \Delta y_{t}=\alpha+\beta t+\gamma y_{t-1}+\delta_{1} \Delta y_{t-1}+\cdots+ \\
& \delta_{p-1} \Delta y_{t-p+1}+\varepsilon_{t}(5)
\end{aligned}
$$

where: $\alpha$ is a constant, $\beta$ is the coefficient on a time trend and $p$ is the lag order of the autoregressive process. Imposing the constraints $\alpha=0$ and $\beta=0$ corresponds to modelling a random walk and using the constraint $\beta=0$ corresponds to modelling a random walk with a drift.

The implementation of Autoregressive Distributed Lag (ARDL)/Bounds testing for estimating the long-run relationships required three basic steps. The first step is to examine the existence of longrun relationships among all the variables in the model. The second step involved estimating long run relationship coefficients with respect to cointegration relations estimated in first step and the third step was estimating short run dynamic coefficients through error correction modelling. 


\section{Nigerian Journal of Basic and Applied Science (December, 2021), 29(2): 17-29}

In order to test the existence of long-run relationship between the variables, there was need to formulate an unrestricted error-correction model (ECM), which is a particular type of ARDL model, as proposed by Pesaran and Shin (1995) and Pesaran, Shin and Smith, (2001).

In this study, the unrestricted error-correction model wasspecified by modifying the three ARDL models specified in (2), (3) and (4).

$$
\begin{aligned}
& \Delta \boldsymbol{T T G D P}_{t}=\alpha_{0}+\sum_{i=1}^{p} \beta_{i} \Delta T T G D P_{t-i}+\sum_{i=0}^{q 1} \Phi_{i} \Delta T R O P E N S_{t-i}+\sum_{i=0}^{q 2} \gamma_{i} \Delta I N F R_{t-i}+\sum_{i=0}^{q 3} \phi_{i} \Delta E X R_{t-i}+\sum_{i=0}^{q 4} \varphi_{i} \Delta A G S G D P_{t-i} \\
& +\sum_{i=0}^{c} \delta_{i} \Delta P C I_{t-i}+\sum_{i=0} \lambda_{i} \Delta F D I S G D P_{t-i}+\sum_{i=0} \psi_{i} \Delta P N M S G D P_{t-i}+\theta_{1} T T G D P_{t-1} \\
& +\theta_{2} \text { TROPNES } S_{t-1} \\
& +\theta_{3} I_{N F R_{t-1}} \theta_{4}+E X R_{t-1}+\theta_{5} A_{G S G D P_{t-1}}+\theta_{6} P C I_{t-1}+\theta_{7} F D I S G D P_{t-1}+ \\
& \theta_{8} P N M S G D P_{t-1}+\varepsilon_{t}(6)
\end{aligned}
$$

$\triangle D T G D P_{t}$

$$
\begin{aligned}
& =\alpha_{n}+\sum^{p} \beta_{i} \Delta D T G D P_{t-i}+P^{q 1} \Phi_{i} \Delta T R O P E N S_{t-i}+P^{q 2} \gamma_{i} \Delta I N F R_{t-i}+P^{q 3} \emptyset_{i} \Delta E X R_{t-i} \\
& +\sum_{i=0}^{q 5} \delta_{i} \Delta P C I_{t-i}+\sum_{i=0}^{q 6} \lambda_{i} \Delta F D I S G D P_{t-i}+\sum_{i=0}^{q 7} \psi_{i} \Delta P N M S G D P_{t-i}+\theta_{1} D T G D P_{t-1} \\
& +\theta_{2} \text { TROPNES } S_{t-1} \\
& +\theta_{3} I N F R_{t-1}+\theta_{4} E X R_{t-1}+\theta_{5} \text { AGSGDP }_{t-1}+\theta_{6} \text { PCI }_{t-1}+\theta_{7} \text { FDISGDP }_{t-1}+ \\
& \theta_{8} \text { PNMSGDP } P_{t-1}+\varepsilon_{t}
\end{aligned}
$$

$\triangle E X T G D P_{t}$

$$
\begin{gathered}
=\alpha_{0}+\sum_{i=1}^{p} \beta_{i} \Delta E X T G D P_{t-i}+\sum_{i=0}^{q 1} \Phi_{i} \Delta T R O P E N S_{t-i}+\sum_{i=0}^{q 2} \gamma_{i} \Delta I N F R_{t-i} \\
+\sum_{i=0} \delta_{i} \Delta P C I_{t-i}+\sum_{i=0} \lambda_{i} \Delta F D I S G D P_{t-i}+\sum_{i=0} \psi_{i} \Delta P N M S G D P_{t-i}+\theta_{1} \text { EXTGDP }_{t-1} \\
+\theta_{2} \text { TROPNES }_{t-1}+ \\
\theta_{3} \text { INFR }_{t-1}+\theta_{4} \text { EXR }_{t-1}+\theta_{5} \text { AGSGDP }_{t-1}+\theta_{6} \text { PCI }_{t-1}+\theta_{7} \text { FDISGDP }_{t-1}+ \\
\theta_{8} \text { PNMSGDP }_{t-1}+\varepsilon_{t} \text { (8) }
\end{gathered}
$$

where:

TTGDP, DTGDP and EXTGDP are the dependent variables while TROPENS, INFR, EXR, AGSGDP, PCl, FDISGDP and PNMSGDP are the explanatory variables. The optimal lag selection in the above models was based on theAkaike Information Criterion(AIC), Schwarz Criterion(SC) (also known as Bayesian
Information Criterion(BIC)), and Hannan-Quinn Information Criterion(HQIC).

After establishing the existence of long-run relationship in equation $(6,7 \& 8)$, we went on to the second step where we estimated the long-run coefficients based on the ARDL ( $p_{1}, q_{1} q_{2} q_{3} q_{4} q_{5}$ $q_{6} q_{7}$ ) model. 
$\operatorname{TTGDP}_{t}$

$$
\begin{aligned}
& =\alpha_{0}+\sum_{i=1}^{p} \theta_{1} \operatorname{TTGDP}_{t-i}+\sum_{i=0}^{q 1} \theta_{2} \operatorname{TROPENS}_{t-i}+\sum_{i=0}^{q 2} \theta_{3} \operatorname{INFR}_{t-i} \\
& +\sum_{i=0}^{q 3} \theta_{4} E X R_{t-i} \\
& +\sum_{i=0}^{q 4} \theta_{5} \operatorname{AGSGDP}_{t-i}+\sum_{i=0}^{q 5} \theta_{6} \text { PCI }_{t-i}+\sum_{i=0}^{q 6} \theta_{7} \text { FDISGDP } P_{t-i}+ \\
& \sum_{i=0}^{q 7} \theta_{8} P N M S G D P_{t-i}+\varepsilon_{t}(9) \\
& =\alpha_{0}+\sum_{i=1}^{p} \theta_{1} \operatorname{DTGDP}_{t-i}+\sum_{i=0}^{q 1} \theta_{2} \operatorname{TROPENS}_{t-i}+\sum_{i=0}^{q 2} \theta_{3} \operatorname{INFR}_{t-i} \\
& +\sum_{i=0}^{q 3} \theta_{4} E X R_{t-i}
\end{aligned}
$$$$
\begin{gathered}
+\sum_{i=0}^{q 4} \theta_{5} A G S G D P_{t-i}+\sum_{i=0}^{q 5} \theta_{6} \text { PCI }_{t-i}+\sum_{i=0}^{q 6} \theta_{7} \text { FDISGDP }_{t-i}+\sum_{i=0}^{q 7} \theta_{8} \text { PNMSGDP }_{t-i} \\
+\varepsilon_{t} \quad(10)
\end{gathered}
$$

EXTGDP $_{t}$

$$
\begin{aligned}
& \alpha_{0}+\sum_{i=1}^{p} \theta_{1} \text { EXTGDP }_{t-i}+\sum_{i=0}^{q 1} \theta_{2} \text { TROPENS }_{t-i}+\sum_{i=0}^{q 2} \theta_{3} I_{N F R_{t-i}} \\
&+\sum_{i=0}^{q 3} \theta_{4} E X R_{t-i} \\
&+\sum_{i=0}^{q 4} \theta_{5} \text { AGSGDP }_{t-i}+\sum_{i=0}^{q 5} \theta_{6} \text { PCI }_{t-i}+\sum_{i=0}^{q 6} \theta_{7} \text { FDISGDP }_{t-i}+\sum_{i=0}^{q 7} \theta_{8} \text { PNMSGDP }_{t-i} \\
&+\varepsilon_{t} \quad(11)
\end{aligned}
$$

The optimal lag length selection for the ARDL ( $p_{1}$, $\left.q_{1} q_{2} q_{3} q_{4} q_{5} q_{6} q_{7}\right)$ is also based on AIC, BIC and HQIC information criteria. In the third step, we estimated the short run dynamic coefficients through error correction model. The standard ECM was estimated as follows: 
$\triangle$ TTGDP $_{t}$

$$
\begin{aligned}
& =\alpha_{0}+\sum_{i=1}^{p} \beta_{i} \Delta T T G D P_{t-i}+\sum_{i=0}^{q 1} \Phi_{i} \Delta T R O P E N S_{t-i}+\sum_{i=0}^{q 2} \gamma_{i} \Delta I N F R_{t-i} \\
& +\sum_{i=0}^{q 3} \emptyset_{i} \Delta E X R_{t-i} \\
& +\sum_{i=0}^{q 4} \varphi_{i} \Delta A G S G D P_{t-i}+\sum_{i=0}^{q 5} \delta_{i} \Delta P C I_{t-i}+\sum_{i=0}^{q 6} \lambda_{i} \Delta F D I S G D P_{t-i}+\sum_{i=0}^{q 7} \psi_{i} \Delta P N M S G D P_{t-i} \\
& +\Omega E C T_{t-1} \varepsilon_{t}(12) \\
& =\alpha_{0}+\sum_{i=1}^{p} \beta_{i} \Delta D T G D P_{t-i}+\sum_{i=0}^{q 1} \Phi_{i} \Delta \operatorname{TROPENS}_{t-i}+\sum_{i=0}^{q 2} \gamma_{i} \Delta I N F R_{t-i} \\
& +\sum_{i=0}^{q 3} \emptyset_{i} \Delta E X R_{t-i} \\
& +\sum_{i=0}^{q 4} \varphi_{i} \Delta A G S G D P_{t-i}+\sum_{i=0}^{q 5} \delta_{i} \Delta P C I_{t-i}+\sum_{i=0}^{q 6} \lambda_{i} \Delta F D I S G D P_{t-i}+ \\
& \sum_{i=0}^{q 7} \psi_{i} \Delta P N M S G D P_{t-i}+\Omega E C T_{t-1}+\varepsilon_{t} \text { (13) }
\end{aligned}
$$

$\triangle E X T G D P_{t}=$$$
\alpha_{0}+\sum_{i=1}^{p} \beta_{i} \Delta E X T G D P_{t-i}+\sum_{i=0}^{q 1} \Phi_{i} \Delta \text { TROPENS }_{t-i}+\sum_{i=0}^{q 2} \gamma_{i} \Delta \text { INFR }_{t-i}+
$$$$
\sum_{i=0}^{q 3} \emptyset_{i} \Delta E X R_{t-i}+\sum_{i=0}^{q 4} \varphi_{i}+\sum_{i=0}^{q 5} \delta_{i} \Delta P C I_{t-i}+\sum_{i=0}^{q 6} \lambda_{i} \Delta F D I S G D P_{t-i}+
$$$$
\sum_{i=0}^{q 7} \psi_{i} \Delta P N M S G D P_{t-i}+\Omega E C T_{t-1}+\varepsilon_{t} \text {, }
$$

Where: $E C T_{t-1}$ is the error correction term lagged by one period, derived from the long-run models (Equation 6, 7 and 8); the parameter $\Omega$ measures the speed of adjustment towards longrun equilibrium and the coefficients $\beta_{i}, \Phi_{i}, \gamma_{i}, \emptyset_{i}, \varphi_{i}, \delta_{i}, \lambda_{i}$ and $\psi_{i}$ represent the short-run dynamics of the model.

\section{RESULTS AND DISCUSSIONS}

After estimating an appropriate version of the unrestricted ECM, the Lagrange Multiplier (LM) Test was performed to test the null hypothesis that the errors were serially independent as against the alternative that the errors were serially dependent. In addition to Lagrange Multiplier (LM) test, this study used the cumulative sum of recursive residuals (CUSUM) and cumulative sum of squares of recursive residuals (CUSUMSQ) tests to determine the stability of the models. These tests were carried out to check the robustness of the model and to ensure that the models were dynamically stable. Finally, the White's (1980) test was performed to test the null hypothesis of no heteroscedasticity in the regression models.

\section{Unit Root Test}

The unit root test was conducted to determine the stationarity of the variables using the Augmented Dickey Fuller (ADF) test. Out of a total of the ten variables tested in this study, five variables were shown to be level stationary series $I(0)$ at the 5 percent level of significance. These are total tax 


\section{Atolagbe and Abiodun: Impact of some Macroeconomic Variables on Tax Revenue in Nigeria}

revenue as a share of GDP (TTGDP), domestic tax revenue as a share of GDP (DTGDP), foreign direct investment as a share of GDP (FDI), inflation rate (INFR), share of petroleum and mining in GDP (PNMSGDP). The other five variables were stationary after first difference $\mathrm{I}(1)$.
These are external tax revenue as a share of GDP (EXTGDP), trade openness (TROPNES), share of agriculture in GDP (AGSGDP), exchange rate (EXR), and per capita income $(\mathrm{PCl})$. Details of the unit root test for each of the ten variables are given in Table 1

Table 1: ADF unit root test of order of integration

\begin{tabular}{|c|c|c|c|c|c|c|}
\hline \multicolumn{4}{|l|}{$\overline{\text { LEVEL }}$} & \multicolumn{3}{|c|}{$1^{1 \text { ST DIFFERENCE }}$} \\
\hline VARIABLES & $\begin{array}{l}\text { ADF } \\
\text { STATISTIC }\end{array}$ & $\begin{array}{l}\text { CRITICAL } \\
\text { VALUE } \\
(5 \%) \\
\end{array}$ & REMARKS & $\begin{array}{l}\text { ADF } \\
\text { STATISTIC }\end{array}$ & $\begin{array}{l}\text { CRITICAL } \\
\text { VALUE } \\
(5 \%) \\
\end{array}$ & $\begin{array}{l}\text { INTEGRATION } \\
\text { ORDER }\end{array}$ \\
\hline DTGDP & -3.1817 & -2.9484 & Stationary & - & - & $1(0)$ \\
\hline FDI & -3.4884 & -2.9484 & Stationary & - & - & $1(0)$ \\
\hline INFR & -3.2701 & -2.9511 & Stationary & - & - & $1(0)$ \\
\hline PNMSGDP & -3.8149 & -2.9484 & Stationary & - & - & $1(0)$ \\
\hline TTGDP & -3.2568 & -2.9484 & Stationary & 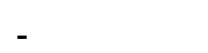 & . & $1(0)$ \\
\hline AGSGDP & - & - & Non Stationary & -6.1078 & -2.9540 & I(1) \\
\hline EXR & - & - & Non Stationary & -3.6494 & -2.9511 & I(1) \\
\hline EXTGDP & - & - & Non Stationary & -6.7105 & -2.9511 & I(1) \\
\hline $\mathrm{PCl}$ & . & - & Non Stationary & -4.9196 & -2.9511 & I(1) \\
\hline TROPNES & - & - & Non Stationary & -8.1411 & -2.9411 & I(1) \\
\hline
\end{tabular}

\section{ARDL Bounds Estimation}

In line with Narayan (2005) and Pesaran et al (2001), the following decision rule has been applied in this study:

i. If computed F-statistics is less than lower bound critical values, the null hypothesis cannot be rejected that there is no long run relationship between variables

ii. If computed F-statistics is greater than the upper bound value, it could be claimed that variables used in the model are cointegrated.

iii. If computed F-statistic falls between the lower and upper bound values, then the test results are inconclusive.

As shown in Table 2, the F-statistic values for model I (4.2869) and model II (4.3689) are greater than the critical value of the upper bound, which is 3.39 in each case at the 5 percent level of significance. Therefore, in each case, we reject the null hypothesis and conclude that there exists a long run relationship between total tax revenue and trade liberalization along with the six macroeconomic variables and between domestic tax revenue and trade liberalization along with the six macroeconomic variables. However, for model III, F (1.6894) < p-value (3.39) at the $5 \%$ level of significance. We therefore do not reject the null hypothesis and hence conclude that there is no long-run relationship between external tax revenue and trade liberalization along with the six macroeconomic variables.

Long Run Estimates Based on AIC-ARDL (1, $0,0,1,0,0,1,1)$

After confirming the existence of long-run cointegration relationship among the variables in models I and II, the long-run relationship between the variables in equations 9 and10 was estimated as specified in Table 3 . The optimal ARDL ( 1,0 , $0,1,0,0,1,1)$ model was selected by the AIC. For model I, the results indicated that the eight variables in aggregate were significant predictors 
of total tax revenue in Nigeria. However, when the variables were examined to evaluate their individual contribution to the model, it was found that all of the variables except inflation rate $(\theta=$ -
$0.029, p=0.5139$ ) made a significant contribution to the model that predicted total tax revenue in Nigeria.

Table 2: Results of ARDL bounds test

\begin{tabular}{|c|c|c|c|c|c|c|}
\hline & $\begin{array}{l}\text { MODEL I } \\
\text { (TTGDP) }\end{array}$ & & $\begin{array}{l}\text { MODEL II } \\
\text { (DTGDP) }\end{array}$ & & $\begin{array}{l}\text { MODEL III } \\
\text { (EXTGDP) }\end{array}$ & \\
\hline Test Statistic & Value & $\mathrm{K}$ & Value & $\mathrm{K}$ & Value & $\mathrm{k}$ \\
\hline F-statistic & 4.286890 & 7 & 4.368867 & 7 & 1.689388 & 7 \\
\hline \multicolumn{7}{|c|}{ Critical Value Bounds } \\
\hline Significance & $\begin{array}{l}\text { Model I } \\
\text { I(0) Bound }\end{array}$ & I(1) Bound & $\begin{array}{l}\text { Model II } \\
\text { I(0) Bound }\end{array}$ & I(1) Bound & $\begin{array}{l}\text { Model III } \\
\text { I(0) Bound }\end{array}$ & I(1) Bound \\
\hline $10 \%$ & 1.95 & 3.06 & 1.95 & 3.06 & 1.95 & 3.06 \\
\hline $5 \%$ & 2.22 & 3.39 & 2.22 & 3.39 & 2.22 & 3.39 \\
\hline $2.5 \%$ & 2.48 & 3.70 & 2.48 & 3.70 & 2.48 & 3.70 \\
\hline $1 \%$ & 2.79 & 4.10 & 2.79 & 4.10 & 2.79 & 4.10 \\
\hline
\end{tabular}

Source: Author's Computation Extract from Eviews 9.0

For model II, the eight variables in aggregate were also significant predictors of domestic tax revenue in Nigeria. However, when the variables were examined to evaluate their individual contribution to the model, it was found that all of the variables except foreign direct investment $(\theta$ $=-2.3026, p=0.3629$ ) made a significant contribution to the model that predicted domestic tax revenue in Nigeria. Results showed that no cointegration relationship existed between the variables in model III as shown in Table 3 and as earlier indicated in Table 2 where $F(1.6894)<p$ value (3.39) at the $5 \%$ level of significance.

Table 3: Long run coefficients

\begin{tabular}{|c|c|c|c|c|c|c|}
\hline VARIABLE & $\begin{array}{l}\text { MODEL I } \\
\text { (TTGDP) } \\
\text { COEFFICIENT }\end{array}$ & $\begin{array}{l}P- \\
\text { VALUE }\end{array}$ & $\begin{array}{l}\text { MODEL II } \\
\text { (DTGDP) } \\
\text { COEFFICIENT }\end{array}$ & $p$-VALUE & $\begin{array}{l}\text { MODEL III } \\
\text { (EXTGDP) } \\
\text { COEFFICIENT }\end{array}$ & $p$-VALUE \\
\hline TROPNES & 0.0263 & 0.039 & 0.0341 & 0.040 & - & - \\
\hline INFR & -0.0286 & 0.513 & -0.025 & 0.020 & - & - \\
\hline EXR & 0.0595 & 0.001 & 0.0632 & 0.000 & - & - \\
\hline AGSGDP & -0.6322 & 0.048 & -0.5528 & 0.004 & - & - \\
\hline $\mathrm{PCl}$ & -0.0032 & 0.016 & -0.0027 & 0.014 & - & - \\
\hline FDI & -2.8797 & 0.053 & -2.3026 & 0.362 & - & - \\
\hline PNMSGDP & 0.4373 & 0.049 & 0.3723 & 0.020 & - & - \\
\hline Constant & 27.9778 & 0.001 & 22.6119 & 0.001 & & \\
\hline
\end{tabular}

Short Run estimates based on AIC-ARDL $(1,0,0$, $1,0,0,1,1)$ for Models I and II and based on VAR Lag Order Selection Criteria for Model III
The results are presented in Table 4. As observed from the table, the lagged error correction terms (ECM) for models I and II have negative coefficients $(-0.9430$ and-1.0199, 


\section{Atolagbe and Abiodun: Impact of some Macroeconomic Variables on Tax Revenue in Nigeria}

respectively) which are statistically significant at the $1 \%$ significance level. By these results, the variables measured in the first and second models are in each case significantly cointegrated and any disequilibrium produced by shocks of previous years would converge back to the longrun equilibrium in the current year at the speed of $94 \%$ and $102 \%$, respectively. The short-run coefficients in Table 4 account for short-run fluctuations not due to deviations from the longrun equilibrium. These results simply showed that in cases of short run shocks, our variables are likely to respond appropriately to equilibrium except in the case of external tax revenue. The results also imply that the variations in both total tax revenue and domestic tax revenue in Nigeria during the period under review were explained in the short-run by trade liberalization along with the other six variables examined in each case. These explain equations 12 and 13. For model III, after confirming that no cointegration relationship exists between the variables, we estimated the short run model using the VAR lag order selection criteria. Equation 14 therefore showed no statistical significance.

Table 4: Cointegration form

\begin{tabular}{lllllll}
\hline & $\begin{array}{l}\text { MODEL I } \\
\text { (TTGDP) }\end{array}$ & & $\begin{array}{l}\text { MODEL II } \\
\text { (DTGDP) }\end{array}$ & $\begin{array}{l}\text { MODEL III } \\
\text { (EXTGDP) }\end{array}$ \\
VARIABLE & COEFFICIENT & $p$-VALUE & COEFFICIENT & $p$-VALUE & COEFFICIENT & $p$-VALUE \\
\hline D(TROPNES) & 0.0248 & 0.594 & 0.0348 & 0.004 & 0.0087 & 0.485 \\
D(INFR) & -0.026 & 0.496 & -0.0254 & 0.466 & -0.0091 & 0.303 \\
D(EXR) & 0.0071 & 0.806 & -0.0051 & 0.841 & 0.0027 & 0.793 \\
D(AGSGDP) & -0.5963 & 0.073 & -0.5638 & 0.036 & -0.0231 & 0.741 \\
D(PCI) & -0.0030 & 0.017 & -0.0028 & 0.015 & 0.0002 & 0.711 \\
D(FDI) & 1.1245 & 0.661 & 1.0512 & 0.646 & -0.1358 & 0.824 \\
D(PNMSGDP) & -0.3876 & 0.529 & -0.3330 & 0.544 & 0.0220 & 0.877 \\
CointEq(-1) & -0.9429 & 0.000 & -1.0198 & 0.000 & -0.0740 & 0.632 \\
\hline
\end{tabular}

Source: Author Computation extract from Eviews 9.0

Table 5: Breusch-Godfrey Serial Correlation LM Test

\begin{tabular}{llll}
\hline \multicolumn{4}{c}{ MODEL I } \\
\hline F-statistic & 0.0721 & Prob. F(2,19) & 0.930 \\
Obs*R-squared & 0.2637 & Prob. Chi-Square (2) & 0.876 \\
& \multicolumn{2}{c}{ MODEL II } & \\
F-statistic & 0.0312 & Prob. F(2,19) & 0.969 \\
Obs*R-squared & 0.1147 & Prob. Chi-Square (2) & 0.944 \\
\hline
\end{tabular}

Heteroscedasticity Test Using the White Test A White test for heteroscedasticity was carried out for models I and II. As observed from the results presented in Table 6 , since the White test statistic is not larger than the critical Chi-square value and that each $F(13,21)$ has a $p$-value greater than 0.05 , we therefore do not have a problem with heteroscedasticity. We do not reject the null hypothesis and hence conclude that there is no heteroscedasticity in the estimated models. 
Nigerian Journal of Basic and Applied Science (December, 2021), 29(2): 17-29

Table 6: Heteroscedasticity test: white test

\begin{tabular}{|c|c|c|c|}
\hline \multicolumn{3}{|c|}{ MODEL I } & \multirow[b]{2}{*}{0.9849} \\
\hline F-statistic & 0.3017 & Prob. $F(13,21)$ & \\
\hline Obs*R-squared & 5.5082 & Prob. Chi-Square(13) & 0.9622 \\
\hline Scaled explained SS & 1.3750 & Prob. Chi-Square(13) & 1.0000 \\
\hline \multicolumn{4}{|c|}{ MODEL II } \\
\hline F-statistic & 0.3018 & Prob. $F(13,21)$ & 0.9849 \\
\hline Obs*R-squa & 5.5103 & Prob. Chi-Square(13) & 0.9622 \\
\hline Scaled explained SS & 1.1591 & Prob. Chi-Square(13) & 1.0000 \\
\hline
\end{tabular}

\section{Cumulative Sum (CUSUM) and Cumulative Sum of Squares (CUSUMSQ) Tests for Stability}

In addition to the Lagrange Multiplier (LM) test performed above, the cumulative sum (CUSUM) of recursive residuals and cumulative sum of squares (CUSUMSQ) of recursive residuals tests were performed to investigate the stability of our models. The graphs of both CUSUM and CUSUMSQ (for both Model I and Model II indicate that there is no instability in the coefficients as the plots of the graphs are confined within the 5 per cent critical bounds of parameter stability, suggesting that all the coefficients of the estimated ARDL models are stable over the period under review (see Figures 1, 2, 3 \& 4 below).

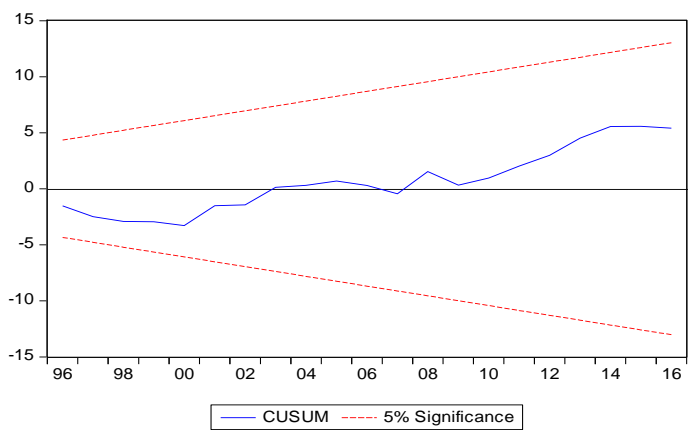

Figure 1: Graph of CUSUM showing stability (Model I)

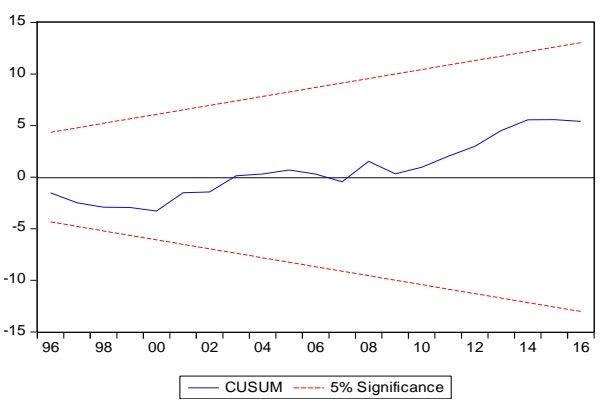

Figure 2: Graph of CUSUMSQ showing stability (Model I)

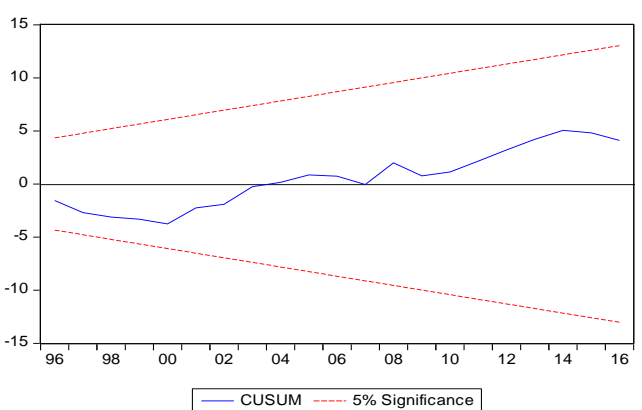

Figure 3: Graph of CUSUM showing sability (Model II)

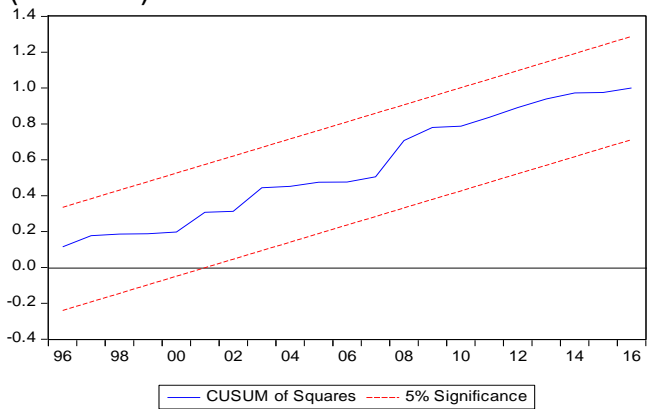

Figure 4: Graph of CUSUMSQ showing stability (Model II) 


\section{Atolagbe and Abiodun: Impact of some Macroeconomic Variables on Tax Revenue in Nigeria}

\section{CONCLUSION}

The study sought to ascertain the effect of trade openness on tax revenue performance in Nigeria. The findings indicated trade liberalization to be the main driver of both total and domestic tax revenues in Nigeria. For every unit increase in trade liberalization the gains in both total and domestic tax revenue rose by about 3 percent. However, trade liberalization and the macroeconomic variables were found to have no long and short run relationship with external tax revenue for the period under review. A number of reasons could be responsible for this and further research may be intended to investigate into this. As found in this study, except inflation rate, all other macroeconomic variables were found to predict total tax revenue, and except foreign direct investment, all other macroeconomic variables predicted domestic tax revenue.

In order to improve Nigeria's total and domestic tax revenues, this study suggests that trade liberalization policies may be implemented, while appropriately regulating key macroeconomic variables such as exchange rate, inflation rate, per capita income, foreign direct investment, share of agriculture in GDP and share of petroleum and mining in GDP.

\section{REFERENCES}

Agbeyegbe, T. D., Stotsky, J., \& WoldeMariam, A. (2006). Trade Liberalisation, Exchange Rate Changes and Tax Revenue in Sub-Saharan Africa. Journal of Asian Economics, 17: 261-284.

Amahalu, N. N., \& Ezechukwu, B.O. (2017). Determinants of audit quality: Evidence from deposit money banks listed on Nigeria Stock Exchange, International Journal of Academic Research in Accounting, Finance and Management Sciences, 7(2): 117-130.

Angour, N., \& Nmili, M. (2019). Estimating Shadow Economy and Tax Evasion: Evidence from Morocco. International Journal of Economics and Finance,
Canadian Center of Science and Education, 11(5), 1-7.

Bhartia, H. L. (2009). Public Finance. 14th Edn., Vikas Publishing House PVT Ltd, New Delhi.

Chartered Institute of Taxation of Nigeria CITN (2002), Nigeria Tax Guide and Statutes. CITN Publication Company Income Tax Nigeria htt://resourcedat.com/2010/12/company income tax (Assessed on 12/07/12).

Dickey, D. \& Fuller, W. (1981). Likelihood Ratio Statistics for Autoregressive Time Series with a Unit Root. Econometrica, 49:10571072.

Ergete, F. \& Bev, D. (2012). The Impact of Tax Cuts on Economic Growth: Evidence From the Canadian Provinces, National Tax Journal, 65:3, pp 563-594.

Feng, Y., \& Suyono, E. (2014). The Relationship between Tax Revenue and Economic Growth of Hebei Province Based on The Tax Multiplier Effect. Global Economy and Finance Journal, 7(2) $1-18$.

Gupta, A. (2007). Determinant of Tax Revenue Effort in Developing Countries.IMF Working Paper WP/07/184.

Herbert, W. E., Nwarogu, I. A., \&Awabueze, C. C. (2018). Tax Reform and Economic Stability. International Journal of Applied Economics, Finance and Accounting, 3(2): 74-87

Institute of Chartered Accountants of Nigeria ICAN (2006), Tax Management and Fiscal Policy in Nigeria 1st edition pp 4650.

International Monetary Fund Annual Report 2018.

James D. G. \& Robert, A. L. (2006). The impact of tax policy on economic growth, income distribution, and allocation of taxes. Social Philosophy and Policy. 23(2): 28 52.

Jhingan, M. L. (2004): Money, Banking, International Trade and Public Finance. Vrinda Publications, New Delhi. 
Kwanashie, M. (1998). Exchange Rate and Trade Liberalization and Non - oil exports in Nigeria. An Empirical Investigation. A Publication of the NSER/SSCN Research Network.

McMahon, G., \& Schmidt-Hebbel, K. (2000). Macroeconomic Adjustment and Tax Reform in Developing Countries. In Perry, G., Whalley, J. and McMahon, G. eds. Fiscal Reform and Structural Change in Developing Countries, Vol. 2, Macmillan Press LtD, London. pp. 150196.

Mehdi, B., Fatemeh A., \& Abdulmajid, A. (2014). Analyzing the effect of economic variables on total tax revenues in Iran. Asian Economic and Financial Review, 4(6): 755-767.

Musgrave, R.A., \& Musgrave, P. B. (2004). Public Finance in Theory and Practice. Tata McGraw Hill, New Delhi, India.

Nwaorgu, I. A., Herbert, W. E., \&Onyilo, F. (2016). A longitudinal assessment of tax reforms and national income in Nigeria: 1971-2014. International Journal of Economics and Finance, 8(8): 43-52.

Okeke, M.N., Mbonu, C.M., \&Ndubuisi, A.N. (2018). Tax Revenue and Economic Development in Nigeria: A Disaggregated Analysis.International Journal of Academic Research in Accounting, Finance and Management Sciences 8(2): 178-199.

Ola, C.S. (2001): Income Tax Law and Practice in Nigeria, 5th edition, Ibadan, Dalag Prints and Park.

Omotosho, M.O. (2001). Principles of Taxation.(1st ed.), Ibadan: D-First Shepherd Investment.

Ordu, P. A., \& Anele, C. A. (2015). A Performance Analysis of Nigerian Tax Objectives Actualization: Evidence of 2000 - 2012. International Journal of Management Science and Business administration, 1(6): 88-100.

Peden, E.A. (1991). Productivity in the United States and Its Relation with Government
Activity: Analysis of 57 years: 1929-1986. Public Choice, 69: 153-173.

Pesaran, M. H., \& Shin, Y. (1995). "An Autoregressive Distributed Lag Modelling Approach to Cointegration Analysis", Cambridge working Paper in Economics 9514, Faculty of Economics, University of Cambridge.

Pesaran, M. H., Shin, Y., \& Smith, R. (2001). Bounds Testing Approaches to the Analysis of Level Relationships, Journal of Applied Econometrics, 16: 289326.

Saibu, O. M., \& Sinbo, O. O. (2013). Macroeconomic Determinants of Tax Revenue in Nigeria (1970-2011). World Applied Sciences Journal. 28: 27-35.

Sanni, A.U. (2007), -Tax Reform in the Capital Market: A Welcome Development. SeminarPaper Ogun State Internal Revenue Service Seminar.

Sumera, M., Khuda, B., \& Sarfraz, H. (2012). Estimating impact of trade liberalization on tax revenue in Pakistan. Journal of Agriculture \& Social Sciences, 8(3): 148150.

Tanzi, V. (1992). Structural factors and tax revenue in developing countries: A decade of evidence. In I. Glodin, \& L. A. Goldin (Eds.), Open Economies: Structural Adjustment and Agriculture (pp. 267-281) Cambridge: Cambridge University Press.

White, H. (1980). A heteroskedastic-consistent covariance matrix estimator and a direct test of heteroskedasticity. Econometrica, 48: 817-838.

World Trade Organization (2013) World Trade Report, Geneva, Switzerland. https://www.wto.org/english/res_e/books p_e/wtr13-2b_e.pdf

Worlu, C. N. and Nkoro, E. (2012). Tax Revenue and Economic Development in Nigeria: A Macroeconometric Approach. Academic Journal of Interdisciplinary Studies. 1(2): 211-223. 